\title{
Pengaruh Persepsi Konsumen pada Iklan Televisi terhadap Minat Beli Produk Mie Sedaap White Curry Studi pada Mahasiswa Fakultas Ekonomi Kampus I Universitas Sanata Dharma
}

\author{
Cicilia Astri Putriwita ${ }^{1}$ \\ ${ }^{1}$ PT Propan Raya ICC, Jakarta \\ ciciliaastri@gmail.com
}

DOI: https://doi.org/10.24071/exero.v3i1.4237

\begin{abstract}
Abstrak
Penelitian ini dilakukan untuk mengetahui persepsi konsumen pada iklan televisi terhadap minat beli konsumen. Penelitian dilakukan pada bulan Agustus 2017 diFakultas Ekonomi Kampus 1 Universitas Sanata Dharma Yogyakarta. Sasaran penelitian ini adalah mahasiswa Fakultas Ekonomi yang pernah menonton iklan produk "Mie Sedaap White Curry" di televisi, namun belum membelinya. Pengambilan sampel menggunakan teknik nonprobability sampling. Data diperoleh dari kuesioner yang diberikan kepada 100 responden. Uji validitas diolah dengan teknik Product Moment dan uji reliabilitas dilakukan dengan rumus Alpha Cronbach. Teknik analisis data dalam penelitian ini adalah analisis regresi sederhana. Kesimpulan dari penelitian ini adalah persepsi konsumen terhadap iklan televisi berpengaruh positif terhadap minat pembeli.
\end{abstract}

Kata kunci: pengaruh persepsi, iklan televisi, kekuatan membeli

\begin{abstract}
This research was conducted to know the consumer perception on television advertising toward the buying interests of the customer. The research was done in August 2017 at the Faculty of Economics Campus 1 Sanata Dharma University, Yogyakarta. The research's target is the Faculty of Economics' students who have watched the advertisement of the product "Mie Sedaap White Curry" in the television, but they have not bought it yet. The samples were taken using nonprobability sampling technic. The data was obtained from questioners given to 100 respondences. The validity test was processed using Product Moment technic and the reliability test was done with Cronbach Alpha formula. Data analysis technic for this research is the simple regression analysis. In conclusion, this research resulted that consumer perception toward television advertising gave positive influence to the buyer interests.
\end{abstract}

Keywords: perception effect, television advertisement, purchasing power

\section{Pendahuluan}

Saat ini masyarakat sudah tidak asing lagi mendengar kata iklan, mereka sudah terbiasa melihat iklan di televisi setiap harinya. Dapat dikatakan dari dulu hingga sampai saat ini iklan terus mengalami perkembangan. Di Indonesia sendiri iklan televisi mulai masuk saat berdirinya Televisi Republik Indonesia atau biasa kita kenal dengan TVRI. Saat itu hanya ada 1 perusahaan yang memproduksi iklan televisi di Indonesia yaitu InterVista. Pada tahun 1963 munculah 3 iklan pertama di Indonesia. Sampai saat ini banyak sekali iklan yang sudah tayang di 
televisi. Banyak perusahaan berlomba-lomba membuat iklan yang dapat menarik minat masyarakat.

Industri periklanan di televisi nasional tak terpengaruh perlambatan ekonomi dan penurunan daya beli masyarakat. Pada Semester I 2016, Adstensity, sebuah aplikasi riset mengenai iklan televisi yang dibesut PT Sigi Kaca Pariwara, mencatat total belanja iklan untuk 13 stasiun televisi nasional mencapai Rp 49,2 triliun. Pendapatan ini naik 49 persen dibanding periode yang sama tahun lalu yang tercatat Rp 32,9 triliun (dalam http://bisnis.liputan6.com, diakses 15 Maret 2017). Dari data tersebut dapat dikatakan iklan merupakan salah satu cara yang efektif bagi perusahaan untuk menawarkan sebuah produk kepada masyarakat.

Salah satu perusahaan yang menggunakan iklan sebagai sumber informasi adalah Wings. Perusahaan Wings berdiri pada tahun 1960 dan telah menghasilkan banyak produk yang dibutuhkan oleh konsumen. Beberapa contoh produk yang dihasilkan adalah Cling, So Klin Lantai, Daia, GIV, TOP Coffee, Floridina, Ale-Ale, Mie Sedaap dan masih banyak lagi. Hampir semua iklan dari produk tersebut pernah kita lihat di televisi. Baru-baru ini Wings mengeluarkan iklan dari produk terbaru mereka, yakni Mie Sedaap White Curry. Selama ini kita mengetahui bahwa Mie Sedaap memiliki varian rasa yang cukup banyak. Salah satu varian rasa yang cukup disukai oleh konsumen adalah Mie Sedaap Kari Spesial. Belum lama ini Mie Sedaap mengeluarkan varian rasa baru yaitu Mie Sedaap White Curry.

Dalam iklan terbaru Mie Sedaap ini, Syahrini ditunjuk sebagai brand ambassador. Didalam iklan tersebut Syahrini menyanyikan sebuah jingle yang menceritakan tentang kelezatan dari Mie Sedaap White Curry. Didalam jingle disebutkan bahwa kelezatan mie ini berasal dari belasan bumbu rempah yang digunakan. Jika dilihat dari jam tayangnya, iklan ini tayang di jam prime time. Diharapkan dengan adanya iklan tersebut, maka akan timbul minat beli dari konsumen.

Minat beli yang timbul pada konsumen, bukan hanya di dasarkan pada pernah atau tidak pernah melihat iklan saja, tetapi ada juga dorongan dari faktor-faktor lain yang menimbulkan keputusan pembelian, seperti: usia, pekerjaan, motivasi, keluarga, pengalaman, sikap, dsb. Minat beli merupakan kecenderungan konsumen untuk membeli suatu merek atau mengambil tindakan yang berhubungan dengan pembelian 
diukur dengan tingkat kemungkinan konsumen melakukan pembelian (Assael: 2001). Dengan membuat iklan yang semenarik mungkin, perusahaan berharap akan timbul minat beli dalam benak masyarakat. Apakah dengan membuat iklan yang menarik dengan bintang iklan artis papan atas, jingle yang mudah diingat serta gambar dan warna yang menarik dapat menimbulkan minat beli pada konsumen? Pertanyaan tersebutlah yang mendorong untuk dilaksanakannya penelitian ini, dengan harapan dapat memberikan jawaban kepada pihak- pihak yang berkepentingan

\section{Kajian Literatur}

Menurut Kasali (2007: 9) iklan didefinisikan sebagai pesan yang menawarkan suatu produk kepada masyarakat melalui suatu media. Iklan adalah segala bentuk presentasi nonpribadi dan promosi gagasan, barang, atau jasa oleh sponsor tertentu yang harus dibayar (Kotler, 2005:277).

Tujuan Periklanan. Selanjutnya menurut Kotler (2005: 278) tujuan dari periklanan dapat digolongkan menurut apakah sasarannya untuk menginformasikan, membujuk, mengingatkan atau memperkuat. Tujuan tersebut diantaranya adalah sebagai berikut:

1) Iklan Informatif

Iklan yang dimaksudkan untuk menciptakan kesadaran dan pengetahuan tentang produk baru atau ciri baru produk yang sudah ada.

2) Iklan Persuasif

Iklan yang dimaksudkan umtuk menciptakan kesukaan, preferensi, keyakinan dan pembelian suatu produk atau jasa.

3) Iklan Pengingat

Iklan yang dimaksudkan untuk merangsang produk dan jasa kembali.

4) Iklan Penguatan

Iklan yang dimaksudkan untuk meyakinkan pembeli sekarang bahwa mereka telah melakukan pembelian yang tepat.

\section{Iklan Media Penyiaran Televisi}

Menurut Morissan (2010: 187) iklan melalui media televisi mempunyai kekuatan, yaitu :

1) Daya Jangkauan Luas

Televisi mampu menjangkau masyarakat yang sangat luas. Karena harganya yang 
sudah semakin terjangkau, hampir setiap keluarga pasti memiliki televisi. Selain itu sekarang ini siaran televisi sudah dinikmati oleh berbagai kelompok masyarakat. Daya jangkau yang luas ini memungkinkan pemasar memperkenalkan dan mempromosikan produk barunya secara serentak dalam wilayah yang luas bahkan ke seluruh wilayah suatu negara.

2) Selektivitas dan Fleksibilitas

Televisi dapat menjangkau audience tertentu dengan adanya variasi komposisi audience sebagai hasil dari isi program, waktu siaran dan cakupan geografis siaran televisi. Selain audience yang besar, televisi juga menawarkan fleksibilitasnya dalam halaudience yang dituju. Jika suatu perusahaan ingin mempromosikan barangnya pada suatu wilayah tertentu, maka perusahaan dapat memasang iklan pada stasiun televise yang terdapat di wilayah bersangkutan.

3) Fokus Perhatian

Siaran iklan televisi akan selalu menjadi pusat perhatian audience pada saat iklan itu ditayangkan. Jika audiens tidak memindah ke stasiun televisi lain, maka audience harus menyaksikan tayangan iklan televisi itu satu persatu. Perhatian audience akan tertuju pada siaran iklan dimaksud ketika iklan tersebut muncul.

4) Kreativitas dan Efek

Televisi merupakan media iklan yang paling efektif dalam menampilkan kreativitas pemasar secara maksimal. Karena dapat menunjukakan cara bekerja suatu produk yang digunakan serta menanamkan aspek hiburan dalam iklan yang ditayangkan.

5) Prestise

Perusahaan yang mengiklankan produknya di televisi biasanya akan menjadi sangat dikenal orang. Baik perusahaan yang memproduksi barang tersebut, barangnya itu sendiri akan menerima status khusus dari masyarakat. Dengan kata lain, produk tersebut mendapatkan prestise tersendiri.

6) Waktu Tertentu

Suatu produk dapat diiklankan di televisi pada waktu-waktu tertentu ketika pembeli potensialnya berada di depan televisi. Dengan demikian, pemasangan iklan dapat menghindari waktu-waktu tertentu pada saat target konsumen mereka tidak menonton televisi. 


\section{Daya Tarik Iklan}

Daya tarik iklan adalah seberapa besar iklan mampu memukau atau menarik perhatian pemirsanya. Iklan yang memiliki daya tarik akan mendapat perhatian yang lebih dari pemirsa. Menurut Kotler dan Armstrong (2008) pembuat iklan harus memikirkan adanya daya tarik, karena menurut mereka daya tarik iklan dapat mempengaruhi efektivitas iklan. Komunikator dalam menyusun pesan iklan harus memikirkan apa yang dikatakan, harus menemukan daya tarik yang mengahsilkan tanggapan yang diinginkan. Pesan-pesan yang akan disampaikan dapat disajikan dengan gaya penyampaian yang berbeda-beda, yaitu dengan menampilkan : cuplikan kehidupan individu atau kelompok, gaya hidup individu, fantasi dengan produk, suasana hati atau citra seputar produk, musik yang lebih menghidupkan pesan, simbol kepribadian untuk menciptakan karakter yang mempersonifikasikan produk, memamerkan keahlian dan pengalaman perusahaan dalam menghasilkan produk, bukti kesaksian dari orang-orang terkenal.

Daya tarik iklan memiliki beberapa jenis yang memuat tujuan dari pengiklan. Menurut Suharno dan Sutarso (2010) ada 3 jenis daya tarik, yaitu :

1) Daya tarik rasional yang berhubungan dengan minat beli khalayak. Daya tarik itu menunjukkan bahwa produk tersebut akan menghasilkan manfaat- manfaat yang diinginkan.

2) Daya tarik emosional yang membangkitkan emosi-emosi baik yang negatif maupun positif yang dapat memotivasi pembelian. Para komunikator mungkin menggunakan daya tarik positif seperti rasa cinta, kebaanggan, kesenangan dan humor. Dapat juga menggunakan daya tarik negatif seperti ketakutan, rasa bersalah dan rasa malu yang mengajak orang-orang untuk melakukan hal-hal yang sebaiknya tidak mereka lakukan.

3) Daya tarik moral yang diarahkan pada "perasaan" khalayak tentang apa yang "benar" dan "pantas". Daya tarik ini sering digunakan untuk mendorong orang peduli dan beramal untuk kegiatan sosial.

Menurut Durianto (2003), daya tarik iklan dapat dikelompokkan dalam dua bagian, yaitu :

1) Daya tarik non verbal

Daya tarik non verbal terlihat dari tampilan wajah dan gerakan tangan. Daya tarik 
non verbal adalah sebagai berikut:

a) Daya tarik pesan

Menurut Suyanto (2005:91) pesan dapat dibuat berdasarkan tingkat yang diinginkan, keeklusifan dan kepercayaan.

b) Slogan

Slogan menurut KBBI (Kamus Besar Bahasa Indonesia) adalah perkataan atau kalimat pendek yang menarik atau mencolok dan mudah diingat untuk memberitahukan sesuattu. Slogan mempunyai dua fungsi utama, yaitu : untuk menjaga menyederhanakan sebuah strategi pesan periklanan agar menjadi jelas, menarik perhatian dan mudah diingat.

2) Daya tarik verbal

Daya tarik verbal ditunjukan dengan kata-kata dan diungkapkan secara lisan maupun tertulis, yang termasuk daya tarik verbal adalah sebagai berikut :

a) Bintang iklan (endoser)

Menurut Shimp (2003: 469), “ Endoser yang menarik akan dapat menarik perhatian audience dan mencontoh, serta mengidentifikasikan diri mereka dengan bintang iklan".

b) Musik (Music)

Menurut Rossiter dan Percy (1997:197) music adalah alunan lagu yang berirama, baik dari suara manusia maupun dari alat-alat. Musik dapat berupa jingle (bunyi-bunyian) atau musik latar belakang.

c) Gambar (Picture)

Menurut Rossiter dan Percy (1997: 197) picture adalah gambar dalam suatu tayangan iklan yang dilihat pemirsa atau masyarakat, yang meliputi objek figur, lokasi, dan latar belakang yang dipakai.

d) Warna (Colour)

Menurut Jefkins (1997: 20), warna sangat efektif dalam membentuk suasana hati pelanggan dan merangsang preperensi atau pilihan pembeli. Dimana perpaduan antara warna dan slogan kata-kata yang unik dan memikat dapat menarik perhatian audience untuk melihat dan merenungkan maknanya. 


\section{Persepsi Konsumen}

Menurut Kotler (2005: 216) persepi merupakan proses yang digunakan oleh individu untuk memilih, mengorganisasi, dan menginterprestasikan masukan informasi guna menciptakan gambaran dunia yang memiliki arti. Persepsi konsumen merupakan proses pengorganisasian, penginterprestasikan terhadap stimulus yang diterima oleh organisme atau individual sehingga merupakan suatu yang berarti, dan merupakan aktivitas yang intregrated dalam diri individu (Walgito, 2004: 70)

Persepsi pada umumnya terjadi karena 2 faktor. Faktor internal berasal dari dalam individu, misalnya sikap, kebiasaan, dan kemauan. Sedangkan faktor eksternal adalah faktor-faktor yang berasal dari luar individu yang meliputi stimulus itu sendiri, baik sosial maupun fisik.

Robbins (2003: 159) menjelakan bahwa meskipun individu-individu memandang pada satu benda yang sama, mereka dapat mempersepsikan berbedabeda. Ada sejumlah faktor yang bekerja untuk membentuk dan terkadang membiaskan persepsi yaitu:

a. Pelaku persepsi.

b. Objek atau yang dipersepsikan.

c. Konteks dari stimulasi dimana persepsi itu dilakukan.

Berbeda dengan persepsi terhadap benda mati seperti meja, mesin atau gedung. Persepsi terhadap individu adalah kesimpulan yang berdasarkan tindakan orang tersebut. Objek yang tidak hidup dikenai hukum-hukum alam tetapi tidak mempunyai keyakinan, motif dan maksud seperti yang ada pada manusia. Akibatnya individu akan berusaha mengembangkan penjelasan mengapa berperilaku dengan cara-cara tertentu. Oleh karena itu, persepsi atau penilaian individu terhadap seseorang akan cukup banyak dipengaruhi oleh pengandaian yang diambil mengenai keadaan internal orang itu.

\section{Minat Beli}

Minat beli merupakan kecenderungan konsumen untuk membeli suatu merek atau mengambil tindakan yang berhubungan dengan pembelian diukur dengan tingkat kemungkinan konsumen melakukan pembelian (Assael : 2001). Menurut Metha mendefinisikan minat beli sebagai kecenderungan konsumen untuk membeli 
suatu merek atau mengambil tindakan yang berhubungan dengan pembelian yang dapat diukur dengan tingkat konsumen melakukan pembelian Metha (1994:66).

Swastha dan Irawan (2001) mengemukakan faktor-faktor yang mempengaruhi minat beli berhubungan dengan perasaan dan emosi, bila seseorang merasa senang dan puas dalam membeli barang atau jasa maka hal itu akan memperkuat minat beli, ketidakpuasaan biasanya menghilangkan minat.

Minat beli dapat diidentifikasiakan melalui indikator- indikator sebagai berikut:

1) Minat transaksional, yaitu kecenderungan seseorang untuk membeli produk.

2) Minat refrensial, yaitu kecenderungan seseorang untuk mereferensikan produk kepada orang lain.

3) Minat preferensial, yaitu minat yang menggambarkan perilaku seseorang yang memiliki preferensial utama pada produk tersebut. Preferensi ini hanya dapat diganti jika terjadi sesuatu dengan produk preferensialnya

4) Minat eksploratif, minat ini menggambarkan perilaku seseorang yang selalu mencari informasi mengenai produk yang diminatinya.

\section{Kerangka Penelitian}

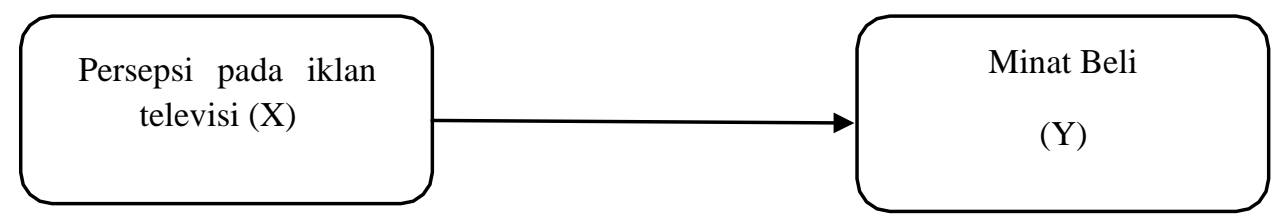

Gambar 1. Kerangka Penelitian

Dari gambar 1 tersebut menunjukkan bahwa persepsi konsumen pada iklan televisi (X) sebagai variabel independen. Sedangkan minat beli konsumen (Y) sebagai variabel dependen.

\section{Metode Penelitian}

Penelitian ini merupakan penelitian studi kasus dengan studi kasus dengan subyek penelitian adalah mahasiswa Fakultas Ekonomi Kampus 1 Universitas Sanata Dharma Yogyakarta, dan obyek penelitiannya adalah persepsi konsumen pada iklan televisi dan minat beli. Penelitian ini dilakukan pada bulan Agustus 2017 di di Fakultas Ekonomi Kampus 1 Universitas Sanata Dharma Yogyakarta. Sampel dalam penelitian ini adalah sebagian mahasiswa Fakultas Ekonomi yang terdiri dari Program Studi Akuntansi angkatan 2014-2016, Program Studi Manajemen angkatan 
2014-2016, dan Program Studi Ekonomi angkatan 2016 yang sudah pernah melihat iklan Mie Sedaap White Curry tetapi belum pernah membeli produk tersebut sejumlah 100 orang, dengan teknik pengambilan sampel Accidental Sampling.

Sumber dan jenis data dalam penelitian ini adalah data primer dan data sekunder. Data primer pada penelitian ini adalah data yang dikumpulkan oleh peneliti yang didapat dari responden yang pernah melihat iklan mie Sedaap White Curry tetapi belum pernah membeli produk tersebut. Sedangkan data sekunder dalam penelitian ini adalah data yang diperoleh peneliti secara tidak langsung melalui media perantara (diperoleh dan dicatat oleh pihak lain, buku yang sudah dipublikasikan maupun yang tidak dipublikasikan, internet, televisi, jurnal penelitian).

Variabel independen dalam penelitian ini adalah persepsi pada daya tarik verbal iklan. Aspek/dimensi verbal yang dipersepsikan, yaitu : bintang iklan, music dalam iklan, gambar iklan, dan komposisi warna serta pengaturan cahaya dalam tayangan iklan. Variabel dependen dalam penelitian ini adalah minat beli. Minat beli merupakan kecenderungan konsumen untuk membeli suatu produk. Indikator dari variabel dependen yaitu: kebersediaan konsumen untuk membeli produk mie Sedaap White Curry, kecenderungan konsumen lebih memilih produk Mie Sedaap White Curry dibanding produk lain, dan ebersediaan konsumen untuk mencari informasi yang berkaitan dengan produk mie Sedaap White Curry.

Pengukuran variabel dalam penelitian ini menggunakan skala rating dengan menggunakan skala Likert. Menurut Sugiyono (2008: 86), skala Likert digunakan untuk mengukur sikap pendapat, dan persepsi seseorang atau sekelompok orang tentang fenomenal sosial.

Penyebaran kuesioner ini dilakukan secara langsung oleh penulis kepada mahasiswa Fakultas Ekonomi Kampus 1 Universitas Sanata Dharma dan disebar sebanyak 100 eksamplar. Dalam pemilihan responden untuk mengisi kuesioner, penulis menanyakan terlebih dahulu calon responden sesuai kriteria yang telah ditentukan sebelumnya, jika calon responden memenuhi kriteria yang diajukan oleh penulis maka calon responden berhak mengisi kuesioner penulis.

Pengisian kuesioner dilakukan dengan cara memberikan tanda (x) pada pernyataan yang telah penulis susun, masing-masing pernyataan telah dicantumkan 5 
pilihan yaitu "SS" sangat setuju. "S" setuju, "N" netral, "TS" tidak setuju, dan "STS" sangat tidak setuju, sehingga responden hanya perlu memilih salah satu pernyataan yang sesuai dengan apa yang mereka alami dan rasakan.

Karakteristik responden yang akan dipaparkan meliputi program studi, jenis kelamin. Data deskriptif yang akan memaparkan skor rata- rata persepsi konsumen pada iklan televisi dan minat beli, sedangkan kuantitatif pada variabel persepsi konsumen pada iklan televisi dan minat beli meliputi uji instrumen (Validitas dan Reliabilitas), uji asumsi klasik (uji normalitas), uji analisis data (analisis regresi linier sederhana) serta pengujian hipotesis (uji t).

Analisis resgresi sederhan dilakukan dengan prosedur sebagai berikut :

1) Menguji Asumsi Klasik

Sebagai prasyarat untuk dapat menggunakan analisis regresi linier sederhana dalam teknik analisis data maka perlu melakukan uji asumsi terlebih dahulu. Uji asumsi dasar yaitu uji normalitas. Uji normalitas memiliki tujuan untuk mengetahui apakah nilai residual yang dihasilkan dari regresi terditribusi secara normal atau tidak. Model regresi yang baik adalah yang memiliki residual yang terdistribusi secara normal. Dalam penelitian ini pengujian normalitas menggunakan rumus kolmogrov-smirnov, dalam hal ini untuk mengetahui apakah suatu data terdistribusi secara normal adalah Jika signifikansi (significance level) lebih dari 0,05 (sign>0,05)

2) Merumuskan Persamaan Regresi Linier Sederhana

Penelitian ini menggunakan analisis regresi linier sederhana dikarenakan hanya terdapat satu variabel independen dan satu variabel dependen. Regresi linier merupakan sebuah prosedur hubungan matematis untuk mengukur ada tidaknya pengaruh dimensi-dimensi pada variabel independen terhadap variabel dependen. Perhitungannya dapat dilakukan dengan menggunakan alat bantu software SPSS. Persamaan garis regresi linear sederhana ditentukan sebagai berikut: $\mathrm{Y}=\mathrm{a}+\mathrm{bX}$

3) Melakukan Pengujian Hipotesis (Uji t)

Berikut langkah-langkah pengujian hipotesis:

a) Merumuskan hipotesis:

Hipotesis merupakan jawaban teoritis atau sementara terhadap permasalahan penelitian yang telah dirumuskan sebelumnya sampai jawaban tersebut terbukti 
melalui data yang telah ditemukan. Dikatakan sementara, karena jawaban yang diberikan baru didasarkan pada teori yang relevan, belum didasarkan pada fakta-fakta empiris yang diperoleh melalui pengumpulan data (Sugiyono, 2009:51). Berdasarakan kerangka penelitian diatas maka penulis merumuskan hipotesis yang merujuk pada rumusan masalah sebagai berikut:

$\mathrm{H}_{0}: \beta=0$, persepsi konsumen pada iklan televisi tidak berpengaruh terhadap minat beli

$\mathrm{H}_{\mathrm{a}}: \beta \neq 0$, persepsi konsumen pada iklan televisi berpengaruh terhadap minat beli

b) Menentukan level of significance $(\alpha)$ :

Taraf signifikansi yang digunakan 0,05 (5\%). Kriteria pengujian:

$\mathrm{H}_{0}$ diterima jika psig $>\alpha=0,05$

$\mathrm{H}_{0}$ ditolak jika psig $\leq \alpha=0,05$

c) Membuat kesimpulan

Jika $\mathrm{H}_{0}$ diterima dan $\mathrm{H}_{\mathrm{a}}$ ditolak berarti persepsi konsumen pada iklan televisi tidak berpengaruh pada minat beli begitu pula sebaliknya jika $\mathrm{H}_{0}$ ditolak dan $\mathrm{H}_{\mathrm{a}}$ diterima maka persepsi konsumen pada iklan berpengaruh terhadap minat beli.

\section{Hasil dan Pembahasan}

\section{Uji Instrumen: Uji Validitas dan Reliabilitas}

Uji Validitas yang digunakan dalam penelitian ini menggunakan teknik korelasi product moment pearson. Dikatakan valid apabila hasil uji didapati $\mathrm{r}_{\text {hitung }} \geq \mathrm{r}_{\text {tabel }}$. dalam pengujian ini dilakukan dengan menggunakan data dari 30 responden pertama. Diketahui $\mathrm{N}=100$ dan $\alpha=5 \%$, maka $\mathrm{r}_{\text {tabel }}(5 \%, 100-2)=0,196$. setiap item akan dinyatakan valid jika $r_{\text {hitung }}>0,196$. Validasi dari item yang diuji adalah sebagai berikut: 


\section{Tabel 1}

Rangkuman Tes Validitas Variabel Bebas

\begin{tabular}{|c|c|c|c|c|c|}
\hline Variabel & Dimensi & Butir & r (hitung) & r (tabel) & Keterangan \\
\hline \multirow{13}{*}{$\begin{array}{l}\text { Persepsi } \\
\text { Konsumen } \\
\text { pada Iklan } \\
\text { Televisi }\end{array}$} & \multirow{4}{*}{$\begin{array}{c}\text { Bintang } \\
\text { Iklan }\end{array}$} & 1 & $0,546 * *$ & 0,196 & VALID \\
\hline & & 2 & $0,448 * *$ & 0,196 & VALID \\
\hline & & 3 & $0,637 * *$ & 0,196 & VALID \\
\hline & & 4 & $0,635 * *$ & 0,196 & VALID \\
\hline & \multirow{3}{*}{ Musik } & 1 & $0,550 * *$ & 0,196 & VALID \\
\hline & & 2 & $0,641 * *$ & 0,196 & VALID \\
\hline & & 3 & $0,581 * *$ & 0,196 & VALID \\
\hline & \multirow{4}{*}{ Gambar } & 1 & $0,307 * *$ & 0,196 & VALID \\
\hline & & 2 & $0,382 * *$ & 0,196 & VALID \\
\hline & & $\overline{3}$ & $0,556 * *$ & 0,196 & VALID \\
\hline & & 4 & $0,477 * *$ & 0,196 & VALID \\
\hline & \multirow[t]{2}{*}{ Warna } & 1 & $0,417 * *$ & 0,196 & VALID \\
\hline & & 2 & $0,431 * *$ & 0,196 & VALID \\
\hline
\end{tabular}

Sumber : Data Primer yang diolah Agustus 2017

Tabel 2

Rangkuman Tes Validitas Variabel Terikat

\begin{tabular}{clllll}
\hline \multirow{2}{*}{ Variabel } & Dimensi & \multirow{2}{*}{ Butir } & $\begin{array}{c}\mathbf{r} \\
\text { (hitung) }\end{array}$ & $\begin{array}{c}\text { r } \\
\text { (tabel) }\end{array}$ & Keterangan \\
\hline \multirow{3}{*}{ Minat Beli } & Transaksional & 1 & $0,667^{* *}$ & 0,196 & VALID \\
\cline { 2 - 6 } & Preferensial & 2 & $0,889^{* *}$ & 0,196 & VALID \\
\cline { 2 - 6 } & Eksploratif & 3 & $0,816^{* *}$ & 0,196 & VALID \\
\hline
\end{tabular}

Sumber: Data Primer yang diolah, Agustus 2017

Berdasarkan tabel 1 dan 2 dapat diketahui bahwa seluruh butir pernyataan pada indikator persepsi konsumen pada iklan televisi dan indikator minat beli mempunyai nilai $r_{h i t u n g}>r_{\text {tabel }}$ sehingga seluruh butir pernyataan dikatakan valid.

Uji reliabilitas digunakan untuk menunjukkan sebuah pengertian bahwa suatu instrumen cukup dipercaya untuk digunakan sebagai alat pengumpul data karena instrumen tersebut sudah baik. ji reliabilitas dalam penelitian ini menggunakan program SPSS 16.0 dengan cara mengukur realibilitas dengan uji statistika Cronbach's Alpha. Suatu dikatakan reliabel jika memberikan nilai Cronbach's Alpha $\geq 0,60$. 
Tabel 3

Hasil Reliabilitas Persepsi Konsumen pada Iklan Televisi

\begin{tabular}{cc}
\hline \multicolumn{2}{c}{ Reliability Statistics } \\
\hline Cronbach's Alpha & N of Items \\
\hline .793 & 14 \\
\hline
\end{tabular}

Sumber data primer SPSS 2016

Berdasarkan dari tabel di atas dapat diketahui dari seluruh item pada variabel persepsi konsumen pada iklan televisi yang berjumlah 14 memiliki nilai Cronbaach's Alpha sebesar 0,793. hal ini menunjukkan bahwa instrumen penelitian yang digunakan dapat diterima dan reliabel karena $0,793 \geq 0,60$.

\begin{tabular}{c} 
Tabel 4 \\
Hasil Reliabilitas Minat Beli \\
\hline \multicolumn{2}{c}{ Reliability Statistics } \\
\hline Cronbach's Alpha $\quad$ N of Items \\
\hline .710 \\
\hline Sumber data primer SPSS 2016
\end{tabular}

Berdasarkan dari tabel di atas dapat diketahui dari seluruh item pada variabel minat beli yang berjumlah 3 memiliki nilai Cronbaach's Alpha sebesar 0,710. Hal ini menunjukkan bahwa instrumen penelitian yang digunakan dapat diterima dan reliabel karena $0,710 \geq 0,60$.

\section{Deskripsi responden}

Menganalisis data yang berkaitan dengan identitas responden yang meliputi program studi dan jenis kelamin. Deskriptif responden dilakukan dengan pendekatan presentase. Dalam penyebaran kuesioner dilakukan di Fakultas Ekonomi Kampus 1 Universitas Sanata Dharma dan dibagikan kepada 100 responden. 


\section{Tabel 5}

Karakteristik Responden Berdasarkan Program Studi

\begin{tabular}{clcc}
\hline No & \multicolumn{1}{c}{ Program Studi } & Jumlah & Presentase \\
\hline 1 & Akuntansi & 42 & $42 \%$ \\
2 & Manajemen & 54 & $54 \%$ \\
3 & Ekonomi & 4 & $4 \%$ \\
\hline \multicolumn{2}{c}{ Jumlah } & 100 & $100 \%$
\end{tabular}

Sumber: Hasil Pengolahan Data Primer, 2017

Berdasarkan tabel 5, dapat diketahui bahwa 42 responden adalah mahasiswa program studi Akuntansi dengan presentase 42\%, 54 responden adalah mahasiswa program studi Manajemen dengan presentase 54\% dan yang terakhir 4 responden berasal dari program sudi ekonomi dengan presentase sebesar 4\% .Dengan demikian dapat diketahui bahwa responden dalam penelitian ini didominasi oleh mahasiswa program studi Manajemen sedangkan yang paling sedikit yaitu program studi Ekonomi.

Tabel 6

Karakteristik Responden Berdasarkan Jenis Kelamin

\begin{tabular}{|c|c|c|c|}
\hline No & Jenis Kelamin & Jumlah & Presentase \\
\hline 1 & Laki-laki & 36 & $36 \%$ \\
\hline 2 & Perempuan & 64 & $64 \%$ \\
\hline & Jumlah & 100 & $100 \%$ \\
\hline
\end{tabular}

Sumber: Hasil Pengolahan Data Primer, 2017

Berdasarkan tabel 6 diketahui nahwa responden dalam penelitian ini terdiri dari 36 laki-laki dengan presentase $36 \%$ dan 64 perempuan dengan presentase sebesar $64 \%$.

\section{Deskripsi Variabel}

Analisis deskripsi dilakukan untuk mengetahui rata-rata skor jawaban responden untuk setiap dimensi variabel persepsi konsumen pada iklan televisi dan indikator minat beli. Metode pengujian rata-rata skor dilakukan dengan menggunakan bantuan MS. Excel. 
Tabel 7

Hasil Analisis Deskriptif Variabel Dimensi dan

Item Persepsi Konsumen pada Iklan Televisi

\begin{tabular}{|c|c|c|c|c|c|}
\hline Variabel & Mean & Dimensi & Mean & Item & Mean \\
\hline \multirow{14}{*}{$\begin{array}{c}\text { Persepsi } \\
\text { Konsumen } \\
\text { pada Iklan } \\
\text { Televisi }\end{array}$} & \multirow{14}{*}{3,59} & \multirow{4}{*}{ Bintang } & \multirow{4}{*}{3,72} & 1 & 3,85 \\
\hline & & & & 2 & 3,97 \\
\hline & & & & 3 & 3,59 \\
\hline & & & & 4 & 3,48 \\
\hline & & \multirow{4}{*}{ Musik } & \multirow{4}{*}{3,50} & 1 & 3,59 \\
\hline & & & & 2 & 3,59 \\
\hline & & & & 3 & 3,52 \\
\hline & & & & 4 & 3,33 \\
\hline & & \multirow{4}{*}{ Gambar } & \multirow{4}{*}{3,50} & 1 & 3,88 \\
\hline & & & & 2 & 3,19 \\
\hline & & & & 3 & 3,46 \\
\hline & & & & 4 & 3,49 \\
\hline & & \multirow[b]{2}{*}{ Warna } & \multirow[b]{2}{*}{3,65} & 1 & 3,55 \\
\hline & & & & 2 & 3,75 \\
\hline
\end{tabular}

Sumber : Data Primer yang diolah, Agustus 2017

Berdasarkan tabel 7, secara umum keseluruhan rata- rata persepsi konsumen pada iklan televisi yaitu 3,59. Angka ini menunjukkan persepsi konsumen pada iklan televisi termasuk dalam kategori baik. Skor rata-rata paling tinggi 3,72 adalah bintang iklan dan yang terendah adalah musik dan gambar dengan rata-rata 3,50. Rata-rata tertinggi sebesar 3,97 ada di item nomor 2 pada dimensi bintang iklan. Selain itu, terdapat item terendah yang termasuk dalam kategori netral yaitu di item nomor 2 pada dimensi warna dengan rata-rata 3,19.

Tabel 8

Deskriptif Variabel dan Indikator Minat Beli

\begin{tabular}{ccll}
\hline Variabel & Mean & \multicolumn{1}{c}{ Indikator } & Mean \\
\hline \multirow{2}{*}{$\begin{array}{c}\text { Minat } \\
\text { Beli }\end{array}$} & \multirow{2}{*}{2,80} & Transaksional & 3,31 \\
\cline { 3 - 4 } & & Preferensial & 2,7 \\
\cline { 3 - 4 } & & Eksploratif & 2,41
\end{tabular}

Sumber: Data yang Diolah, Agustus 2017

Berdasarkan tabel 8, secara umum keseluruhan rata-rata minat beli yaitu 2,80 yang termasuk dalam kategori netral. Jika dilihat dari rata-rata skor indikator yang 
tertinggi adalah minat transaksional dengan rata-rata 3,31 yang termasuk dalam kategori netral dan yang terendah yaitu minat eksploratif dengan rata-rata 2,41 yang termasuk dalam kategori rendah.

\section{Uji Asumsi Klasik}

Uji asumsi klasik yang digunakan dalam penelitian ini adalah uji normalitas. Uji normalitas bertujuan untuk mengetahui normal atau tidaknya suatu distribusi data. Normal aatau tidaknya distribusi data dilakukan dengan melihat nilai signifikan pada tabel Kolmogorov- Smirnov. Jika nilai signifikan lebih besar dari 0,05 (sign $>0,05)$ berarti data berdistribusi normal. Berdasarkan perhitungan dengan program SPPS dapat diketahui bahwa nilai sig. pada bagian Kolmogorov-Smirnov sebesar 0,874 >0,05. Jadi, semua variabel dalam penelitian ini berdistribusi normal.

\section{Persamaan Regresi Sederhana}

Analisis regresi sederhana bertujuan untuk mengetahui arah hubungan antara variabel independen dengan variabel dependen. Selain untuk mengetahui arah hubungan kedua variabel analisis regresi sederhana juga untuk memprediksi nilai dari variabel dependen apabila variabel independen mengalami kenaikan atau penurunan. Adapun hasil analisis regresi linier sederhana sebagai berikut: $Y=0,411$ $+0,667 \mathrm{X}$.

\section{Uji Hipotesis (Uji t)}

Uji t dilakukan untuk mengetahui pengaruh secara signifikan antara variabel bebas $(\mathrm{X})$ terhadap variabel terikat $(\mathrm{Y})$.

1) Menentukan rumusan hipotesis

$\mathrm{H}_{0}: \beta=0$, persepsi konsumen pada iklan televisi tidak berpengaruh terhadap minat beli.

$\mathrm{H}_{\mathrm{a}}: \beta \neq 0$, persepsi konsumen pada iklan televisi berpengaruh terhadap minat beli.

2) Menentukan level of significance $(\alpha)$ :

Taraf signifikansi yang digunakan 0,05 (5\%) Kriteria pengujian: $\mathrm{H}_{0}$ diterima jika psig $>\alpha=0,05 \mathrm{H}_{0}$ ditolak jika psig $\leq \alpha=0,05$ 
3) Membuat kesimpulan

Dari perhitungan SPPP diketahui bahwa nilai signifikansi persepsi konsumen pada iklan televisi adalah sebesar 0.000. nilai signifikan tersebut lebih kecil dari $0.05(0,000 \leq 0,05)$. Maka Ho ditolak dan Ha diterima. Artinya persepsi konsumen pada iklan televisi berpengaruh terhadap minat beli.

\section{Pembahasan}

Dilihat dari hasil analisis deskriptif tabel 7 dapat dilihat variabel persepsi konsumen pada iklan televisi memiliki rata-rata sebesar 3,59. Dimana rata-rata tersebut masuk dalam kategori baik. Artinya iklan yang ditayangkan ditelevisi sudah bisa mempengaruhi responden.

Jika dilihat lebih detail dari dimensi yang diteliti, bintang iklan memiliki ratarata sebesar 3,72 yang masuk dalam kategori baik. Rata- rata terendah sebesar 3,48 ada pada item nomor 4 tentang kejelasan informasi yang disampaikan oleh bintang iklan. Walaupun demikian, rata-rata item nomor 4 masih masuk dalam kategori baik. Artinya para responden sudah merasa informasi yang disampaikan bintang iklan sudah jelas.

Dimensi yang ke 2 adalah musik. Rata-rata untuk dimensi musik sebesar 3,50 yang masuk dalam kategori baik. Rata-rata terendah ada pada item nomor 4 sebesar 3,33 yang membahas tentang kesesuaian jingle dengan konsep iklan yang lebih digunakan. Meskipun demikian, rata-rata tersebut masuk dalam kategori netral. Artinya para responden merasa jingle dan konsep yang digunakan dalam iklan biasa saja.

Dimensi yang ke 3 adalah gambar. Rata-rata dari dimensi ini sebesar 3,50. Sama seperti dimensi musik, dimensi ini masuk dalam kategori baik. Rata-rata terendah terdapat pada item nomor 2 sebesar 3,19 tentang kesesuaian gambar dengan kenyataan. Rata-rata tersebut masuk dalam kategori netral. Artinya responden merasa biasa saja saat membandingkan gambar yang ada pada iklan dengan kenyataan yang ada.

Dan dimensi yang ke 4 untuk persepsi konsumen pada iklan televisi adalah warna. Rata-rata pada dimensi warna sebesar 3,65 yang masuk dalam kategori baik. Item nomor 1 membahas tentang warna ditampilkan dapat menarik perhatian, yang 
memiliki rata-rata terendah yaitu sebesar 3,55 dan masuk dalam kategori baik. Artinya warna dominan yang ditampilkan dalam iklan mudah diingat oleh responden. Untuk variabel terikat yaitu minat beli, dapat dilihat dari tabel 8. Dalam tabel tersebut dapat dilihat bahwa rata-rata dari minat beli adalah sebesar 2,80 dan masuk dalam kategori netral. Artinya minat beli yang timbul karena adanya persepsi konsumen konsumen pada iklan televisi tidak rendah dan juga tidak tinggi. Dimensi terendah ada pada minat beli eksploratif dengan rata-rata sebesar 2,41 yang masuk pada kategori rendah.

Melalui uji t diketahui bahwa variabel persepsi konsumen pada iklan televisi berpengaruh terhadap minat beli. Dalam uji t juga dapat diketahui bahwa arah model regresi yang terbentuk adalah positif. Artinya apabila skor pada persepsi konsumen semakin baik, maka minat beli yang muncul juga akan semakin tinggi. Apabila iklan yang ditampilkan di televisi semakin baik atau menarik maka kemungkinan timbulnya minat beli pada orang yang melihat iklan tersebut juga akan semakin tinggi.

Oleh karena itu bila perusahaan ingin menimbulkan minat beli yang lebih tinggi lagi pada masyarakat lewat iklan di televisi maka perusahaan harus meningkatkan persepsi konsumen pada iklan televisi menjadi lebih baik, perusahaan dapat melihat dari rata-rata item terendah dari dua dimensi dengan rata-rata terendah tentang musik dan gambar, sebaiknya perusahaan meningkatkan persepsi konsumen dengan cara lebih menyesuaikan jingle yang digunakan dengan konsep iklan yang ada agar dapat lebih mmenarik perhatian penonton. Penggunaan gambar dalam iklan juga harus perhatikan oleh perusahaan, seperti misalkan menggunakan gambar yang terlihat lebih sesuai dengan kenyataan yang ada.

\section{Kesimpulan, Implikasi, Saran dan Keterbatasan}

\section{Kesimpulan}

1) Persepsi konsumen pada iklan televisi produk mie Sedaap White Curry termasuk dalam kategori baik

2) Minat beli pada produk mie Sedaap White Curry termasuk dalam kategori netral

3) Persepsi konsumen pada iklan televisi berpengaruh terhadap minat beli produk mie Sedaap White Cutty 


\section{Saran}

1) Sebaiknya perusahaan meningkatkan persepsi konsumen pada iklan televisi dengan cara memperbaiki iklan dalam dimensi gambar. Sebaiknya gambar yang dimuat dalam lebih sesuai dengan kenyataan yang ada dan lebih menyesuaikan konsep dengan jingle, sehingga para calon konsumen akan memiliki persepsi yang lebih baik pada iklan televisi produk mie Sedaap White Curry.

2) Hasil penelitian menunjukkan bahwa persepsi pada iklan televisi mempengaruhi minat beli. Ada baiknya peneliti selanjutnya menambah variable lain yang mempengaruhi minat beli.

\section{Keterbatasan}

1) Alternatif jawaban kuisioner yang diberikan menggunakan format ganjil sehingga ada kemungkinan banyak responden yang memilih alternatif jawaban tengah.

2) Penelitian yang dilakukan penulis hanya melihat minat beli pada mahasiswa Fakultas Ekonomi Kampus 1 Universitas Sanata Dharma Yogyakarta. Sehingga tidak dapat digeneralisasi pada ruang lingkup umum.

\section{Referensi}

Arindita, S. 2003. Hubungan antara Persepsi Kualitas Pelayanan dan Citra Bank dengan Loyalitas Nasabah. Skripsi, Surakarta: Fakultas Psikologi Universitas Muhammadiyah Yogyakarta.

Assael, Henry. 2001. Consumen Behavior $6^{\text {th }}$ Edition. New York: Thomson Learning.

Bimo, Walgito. 2004. Pengantar Psikologi Umum. Jakarta: Andi.

Chrisanti, Agnes Yuanita. 2008. Pengaruh Persepsi Konsumen Pada Iklan Televisi Terhadap Minat Beli Konsumen. Skripsi: Universitas Sanata Dharma.

Durianto, Sugiarto, Widjaja dan Supratikno. 2003. Invasi Pasar Dengan Iklan Yang Efektif. Jakarta: PT Gramedia Pustaka Utama.

Ghozali, Imam. 2006. Aplikasi Analisis Multivariate Dengan Program SPSS Edisi 4. Semarang: Badan Penerbit Universitas Diponegoro.

Hamka, M. Pengaruh persepsi Kerja Terhadap Motivasi Berprestasi.

Skripsi (tidak diterbitkan). Fakultas Ekonomi. Surakarta: UMS

http://ayufirdasari.blogspot.co.id/p/blog-page.html.Diakses pada 20 agustus 2017

http://bisnis.liputan6.com. Diakses tanggal 15 Maret 2017.

Jefkins, Frank. 1997. Periklanan. Jakarta: Erlangga.

Kasali, Rhenald. 2009. Manajemen Periklanan: Konsep dan Aplikasinya Di Indonesia. Jakarta: PT Pustaka Utama Grafiti.

Kotler, Philip. 2005. Manajemen Pemasaran, Edisi II Jilid 1 dan 2. Jakarta : PT Indeks.

Kotler dan Keller. 2007. Manajemen Pemasaran Edisi 12. Jilid 1. Jakarta: PT Indeks. 
Kotler, Philip dan Kevin Lane Keller. 2008 (terj Benyamin Motan).

Manajemen Pemasaran Edisi 12. Jilid 1. Jakarta: PT Indeks.

Kotler dan Armstrong G. 2008. Prinsip-Prinsip Pemasaran I Edisi 12. Jilid 2. Jakarta: Erlangga.

Kotler, Philip dan Kevin Lane Keller. 2009 (terj Bob Sebran). Manajemen Pemasaran Edisi 13. Jilid 2. Jakarta: Erlangga.

Mehta, Abhilasha. 1994. How Advertidsing Respon Modeling (ARM) can Increase the Non-Deceptive Counterfeits Journal of Scinetific Research.

Morrisan, M.A. 2010. Periklanan : Komunikasi Pemasaran Terpadu. Jakarta: Kencana.

Robbins, S.P. 2003. Perilaku Organisasi. Jilid I. Jakarta: PT INDEKS Kelompok Gramedia.

Rossiter, John R \& Percy. 1997. Advertising and Promotion Management.

Mc Graw-Hill Book Company: United States of Amerika

Shimp, Terence A. 2003. Periklanan Promosi. Jakarta: Erlangga.

Sugiyono. 2008. Statistika Untuk Penelitian. Bandung: Alfabeta.

Sugiyono. 2013. Metodelogi Penelitian Manajemen. Bandung: Alfabeta.

Sunarno dan Sutarso, Yudi. 2010. Marketing in Practice. Yogyakarta: Graha Ilmu.

Suyanto. 2005. Analisis Dan Desain Aplikasi Multimedia Untuk Pemasaran.

Yogyakarta: Penerbit Andi.

Swastha, B. Irawan, H. 2001. Manajemen Pemasaran Manajemen Pemasaran Modern. Yogyakarta: Liberty.

Tjitono, Fandy. 2008. Strategi Bisnis Pemasaran. Yogyakarta: Penerbit Andi. www.seputarpengetahuan.com. Diakses tanggal 15 Maret 2017. 